\title{
EFFECT OF pH ON THE PRODUCTION \\ OF VOLATILE FATTY ACIDS \\ IN DARK FERMENTATION PROCESS OF ORGANIC WASTE
}

\author{
WPEYW pH NA PRODUKCJĘ LOTNYCH KWASÓW TŁUSZCZOWYCH \\ W PROCESIE FERMENTACJI CIEMNEJ ODPADÓW ORGANICZNYCH
}

\begin{abstract}
The aim of this study was to investigate the effect of $\mathrm{pH}$ on the dark fermentation process of kitchen waste by specifying the composition of the volatile fatty acids (VFA), $\mathrm{H}_{2}$ and by drawing the carbon balance. Studies were carried out in $8 \mathrm{dm}^{3}$ batch bioreactor in mesophilic conditions. The kitchen waste from the city of Lodz were used as a substrate. Based on the study, it was observed that most of the VFA was produced during the first two days of the process, while in the following days the production was diminished. The highest production of VFA $\left(19.5 \mathrm{~g} / \mathrm{dm}^{3}\right)$ was obtained in the bioreactor, where the $\mathrm{pH}$ was 7 and 8 . Analyzing the produced VFA it was observed that mostly the acetic and butyric acid had been produced. Most of acetic acid (over $70 \%$ ) was obtained in fermenter with pH 7 and 8 . In contrast, most of the butyric acid (over $40 \%$ ) was in the bioreactor with a pH of 6. Production of $\mathrm{H}_{2}$ was in the range from 4.29 to $26.5 \mathrm{dm}^{3}$, wherein the largest amount of $\mathrm{H}_{2}$ was created in the bioreactor with a $\mathrm{pH}$ of 6 .
\end{abstract}

Keywords: kitchen waste, volatile fatty acids, dark fermentation, hydrogen

\section{Introduction}

The activities we perform every day in the kitchen or home garden generate huge amounts of waste. A considerable percentage constitute biodegradable waste (up to $50 \%$ ), that most often are stored on landfills or are composted [1]. The amount of food waste generated by urban areas has increased significantly in recent years, which, among others, is inextricably linked to a rising standard of living. Considering the shrinking natural resources and the rapid progress of civilization, more often the reuse of food waste is taken into account as an alternative source of energy. Food waste, including household kitchen waste (KW) could be one of the cheapest and easiest sources of this substrate [2].

Kitchen waste are rich source of carbon, nitrogen and trace elements. It is used for example as feed for livestock (approx. 80\% of KW) [3]. At the same time, high humidity and high salt content cause additional energy consumption in the combustion process of

\footnotetext{
${ }^{1}$ Faculty of Process and Environmental Engineering, Lodz University of Technology, ul. Wólczańska 213, 90-924 Łódź, Poland

*Corresponding author: justyna_grzelak@hotmail.com
} 
KW. This process is also accompanied by the production and release of toxic pollutants into the environment. These negative aspects does not favor the process of combustion, what restricts the use of KW [4]. There are many methods available for treatment of organic waste [5], but it seems that the process of anaerobic fermentation is the most promising method to deal with the problem of increasing amount of generated waste.

Methane fermentation involves series of steps such as hydrolysis, acidogenesis, acetogenesis and methanogenesis [6]. Under controlled conditions, this process provides a useful product, such as $\mathrm{CH}_{4}$, which is considered to be relatively cleaner than fossil fuels. Dark fermentation is a modified version of classic fermentation process, where 3 -stage anaerobic process can be distinguished: hydrolysis, acidogenesis and acetogenesis. During the hydrolysis step, decomposition of polymers contained in waste to monomers is taking place to make it more easily digestible for microorganisms. Then acetogenic and acidogenic bacteria metabolize collected monomers to volatile fatty acids (VFA), including acetic and butyric acid and $\mathrm{H}_{2}$ [7]. In the process of dark fermentation, methanogenesis is eliminated to prevent the conversion of synthesized VFA into methane [8]. VFA serve not only as a substrate for the production of $\mathrm{H}_{2}$ or $\mathrm{CH}_{4}$. They are also used in microbial fuel cells, biological wastewater treatment plants or as a substrate for the production of lipids used in biodiesel production [2]. VFA may be also a substrate for the synthesis of biodegradable polymers (polyhydroxyalkanoate) by specially selected strains of bacteria, e.g. Cupriavidus necator [2].

The dark fermentation process is the most promising and at the same time, the least harmful to the environment among the available methods of $\mathrm{H}_{2}$ synthesis. It solves the problem of obtaining energy from waste materials and eliminates the problem of collecting waste on landfills [9]. The bacteria involved in the dark fermentation reaction, such as Clostridium, convert VFA into acetate, $\mathrm{CO}_{2}$ and $\mathrm{H}_{2}$ during the acetogenic phase [10]. Nowadays, the $\mathrm{H}_{2}$ generation in the dark fermentation process is gaining an increasing number of fans, mainly because this technology enables usage of a wide range of substrates, including renewable resources particularly rich in organic matter, such as sludge, leachate, pomace or waste of food origin [11].

A number of parameters affect the amount and the composition of the produced VFA, including $\mathrm{pH}$, temperature, inoculum or the type and quantity of organic load [2]. Most studied parameter that can regulate those mentioned factors is the $\mathrm{pH}$ of the environment in which the process is carried out [9, 12-17]. Adjusting the $\mathrm{pH}$ affects, among others, intra- and extracellular transport of VFA, which is translated directly into an efficiency of hydrolysis and subsequent fermentation stages [18]. Temudo et al. [19] have shown that depending on the $\mathrm{pH}$, different groups of microorganisms begin to dominate the fermentation process, which has a direct impact on the type of product generated by them, including VFA.

In the process of dark fermentation the compliance of carbon balance was hardly studied. The calculations were mainly limited to the total amount of generated carbon dioxide related to the amount of carbon indicated at the beginning of the process [12].

In the present study the effect of $\mathrm{pH}$ on the composition and amount of VFA obtained in the dark fermentation process of the KW was investigated. Experiments were performed at $\mathrm{pH} 6,7$ and 8 , and without $\mathrm{pH}$ adjustment. In addition to the quantitative and qualitative VFA analysis, the changes in $\mathrm{pH}$, the $\mathrm{C} / \mathrm{N}$ ratio in the feedstock and the production of gases: $\mathrm{CO}_{2}$ and $\mathrm{H}_{2}$ were monitored during the process. On the basis of determined carbon 
amount in liquid and solid phase and the amount of produced $\mathrm{CO}_{2}$, the balance of the carbon fluxes during the fermentation process was calculated.

\section{Materials and methods}

The substrate for the production of VFA in the dark fermentation was selectively collected and then shredded $\mathrm{KW}$ from households, later stored at $-20^{\circ} \mathrm{C}$. Inoculum for the process was the digested sludge from the anaerobic Wastewater Treatment Plant in Lodz. The digested sludge was heated at $70{ }^{\circ} \mathrm{C}$ for 30 minutes to eliminate the methanogenic bacteria growth [12]. The amount of volatile solids (VS) in sludge was $20.06 \mathrm{~g} / \mathrm{dm}^{3}$ and in organic matter it was $0.271 \mathrm{~g} / \mathrm{g}$. The characteristics of the sludge and $\mathrm{KW}$ properties are presented in Table 1.

Table 1

The amount of total solids (TS) and volatile solids (VS) in KW (substrate) and digested sludge (inoculum)

\begin{tabular}{|c|c|c|}
\hline \multirow{2}{*}{ Digested sludge } & TS $\left[\mathrm{g} / \mathrm{dm}^{3}\right]$ & $31.46 \pm 0.23$ \\
\cline { 2 - 3 } & $\mathrm{VS}\left[\mathrm{g} / \mathrm{dm}^{3}\right]$ & $20.06 \pm 0.13$ \\
\hline \multirow{2}{*}{ KW } & $\mathrm{TS}[\mathrm{g} / \mathrm{g}]$ & $0.286 \pm 0.004$ \\
\cline { 2 - 3 } & $\mathrm{VS}[\mathrm{g} / \mathrm{g}]$ & $0.271 \pm 0.003$ \\
\hline
\end{tabular}

In presented study four different dark fermentation processes were conducted: in three of them the $\mathrm{pH}$ was kept constant at the level of 6,7 and 8, and one process was performed with no $\mathrm{pH}$ adjustment. $\mathrm{pH}$ control was carried out with $\mathrm{NaOH}$. The dark fermentation process for all $\mathrm{pH}$ series was conducted in batch bioreactor and it took 7 days. Reaction volume was $8 \mathrm{dm}^{3}$. The process run under fully anaerobic conditions at $37.0 \pm 0.2{ }^{\circ} \mathrm{C}$. The volumetric ratio of organic matter to sludge was $1: 1$. The content of organic dry matter was in the range of 33.88 to $36.12 \mathrm{~g} / \mathrm{dm}^{3}$, and the $\mathrm{C} / \mathrm{N}$ ratio between 10.02 to 12.04 . To ensure completely anaerobic conditions each bioreactor at the start of the process and during each sampling was flushed with nitrogen for 5 minutes. Each experiment was performed in triplicate.

The samples for analysis were collected each day of the process. Three separate fractions were analyzed during the fermentation process: solid, liquid and gas. All fractions were analyzed in triplicates.

The separation of solid and liquid fraction was carried out in a centrifuge MPW 250 (MPW Med-Instruments) at 13,000 rpm for $15 \mathrm{~min}$. For solid phase samples, there were carried out elemental analysis, calculated TS and VS. Elemental analysis, to determine the level of carbon, nitrogen and hydrogen in the samples, was carried out using an elemental analyzer 2500 (CE Instruments). The TS content and VS matter were determined by gravimetric method. All analysis were conducted in accordance with standard methodology [20].

In the liquid phase the concentration and composition of the VFA, total organic carbon (TOC), total nitrogen (TN) and $\mathrm{pH}$ were indicated. TOC and $\mathrm{TN}$ was measured using the IL550 TOC_TN apparatus from Lachat Instruments. The pH measurement was performed using an electrode Mettler Toledo InPro 3250/225/PT1000. The concentration of VFA was measured using Varian CP4800 chromatograph equipped with a capillary column type BP21 $(25 \mathrm{~m}, 0.25 \mathrm{~mm}, 0.25 \mu \mathrm{m})$. Injector and FID detector temperature was $250{ }^{\circ} \mathrm{C}$. Before the samples from bioreactor were loaded on chromatograph, they were filtered using filters 
$0.2 \mu \mathrm{m}$ and acidified with formic acid. $1 \mathrm{~mm}^{3}$ samples were injected into the dispenser with the 1:100 split. After starting the measurement the oven temperature was set $110{ }^{\circ} \mathrm{C}$ for 1 minute, then the temperature raised to $230{ }^{\circ} \mathrm{C}$ with $10{ }^{\circ} \mathrm{C} / \mathrm{min}$ speed and finally maintained $230{ }^{\circ} \mathrm{C}$ for $2 \mathrm{~min}$. Helium was the carrier gas set on $1.4 \mathrm{~cm}^{3} / \mathrm{min}$ flow.

The gas fraction was examined to read the content of $\mathrm{CO}_{2}, \mathrm{CH}_{4}$ and $\mathrm{H}_{2}$. The concentration of gases were measured using a gas chromatograph type 8610C (SRI Instruments) equipped with two packed columns (molecular sieve and silica gel) with a length of $1 \mathrm{~m}, 1 / 8^{\prime \prime}$ diameter and TCD detector. Oven and detector temperature was $60^{\circ} \mathrm{C}$ and $150{ }^{\circ} \mathrm{C}$, respectively. The carrier gas was helium, the flow through the column was set at $10 \mathrm{~cm}^{3} / \mathrm{min}$. The quantity of gas was measured with the water displacement method: bioreactor was attached to a $20 \mathrm{dm}^{3}$ cylinder with brine $(30 \% \mathrm{NaCl}$ in water), which accumulated biogas produced during the process.

\section{Results and discussion}

Dark fermentation process was analyzed each day in terms of quantity and composition of the VFA in the liquid fraction. In all series the highest production of VFA was observed in the first two days of the experiment. In the subsequent days the process significantly slowed down (Fig. 1). Similar results were achieved in Liu et al. experiments [21], who studied the process of VFA synthesis using activated sludge at a $\mathrm{pH}$ range from 3 to 12 for 10 days. Although in total the highest amount of VFA were found on the last day of the process, the synthesis was the most intensive in the 2-3 day. Liu et al. [21] assumed that one of the reasons for this, was the high protein content of the fermentation broth $(60 \%)$. This also suggests an analogy for the process analyzed in this paper. Although the protein content was not measured directly, the low value of $\mathrm{C} / \mathrm{N}$ can indicate this (data quoted later in the article).

Biosynthesis of VFA most extensively occurred at $\mathrm{pH} 7$ and 8 reaching the concentration of $19.5 \mathrm{~g} / \mathrm{dm}^{3}$. For $\mathrm{pH} 6$ the maximum value of generated VFA was $14.1 \mathrm{~g} / \mathrm{dm}^{3}$. Minimum value of VFA $-9.39 \mathrm{~g} / \mathrm{dm}^{3}$ was found in bioreactor without $\mathrm{pH}$ control. Comparing those data with the results of other authors, similar effects achieved He et al. [22], who obtained VFA concentration of $18.46 \mathrm{~g} / \mathrm{dm}^{3}$ from food wastes and Zhang et al. [23] reaching up to $36 \mathrm{~g} / \mathrm{dm}^{3}$ of VFA from kitchen wastes, both at $\mathrm{pH} 7$. The results published by Hong et al. [24] also showed that $\mathrm{pH} 7$ was optimal for VFA synthesis. In the semi-continuous process, with the hydraulic retention time of 9 days and the addition of food wastes on the level of $8.31 \mathrm{~g} / \mathrm{dm}^{3} / \mathrm{d}$ Hong et al. [24] obtained up to $29.1 \mathrm{~g} / \mathrm{dm}^{3}$. Feng et al. [25] and Yuan et al. [17] by fermenting sludge, reached a maximum of VFA production in 8-day fermentation process at $\mathrm{pH} 8$ and 10, respectively, which was three times more than in the non-controlled $\mathrm{pH}$. As confirmed above, maintaining an alkaline $\mathrm{pH}$ favors the production of VFA. One of the reason for this may be intensification of hydrolysis in alkaline medium, which affects the dissociation of the acid moieties of the polymers contained in the substrate and inoculum, which facilitates the distribution of the monomers [25]. It has been shown that maintaining a $\mathrm{pH}$ of 8-10 for the hydrolysis step results in increased availability of soluble organic compounds that are next consumed in the fermentation by microorganisms [26]. In addition, a significant increase of VFA production may be affected by the high protein content of the sludge, which are easily absorbed in the $\mathrm{pH}$ range of 7-10 [21]. 


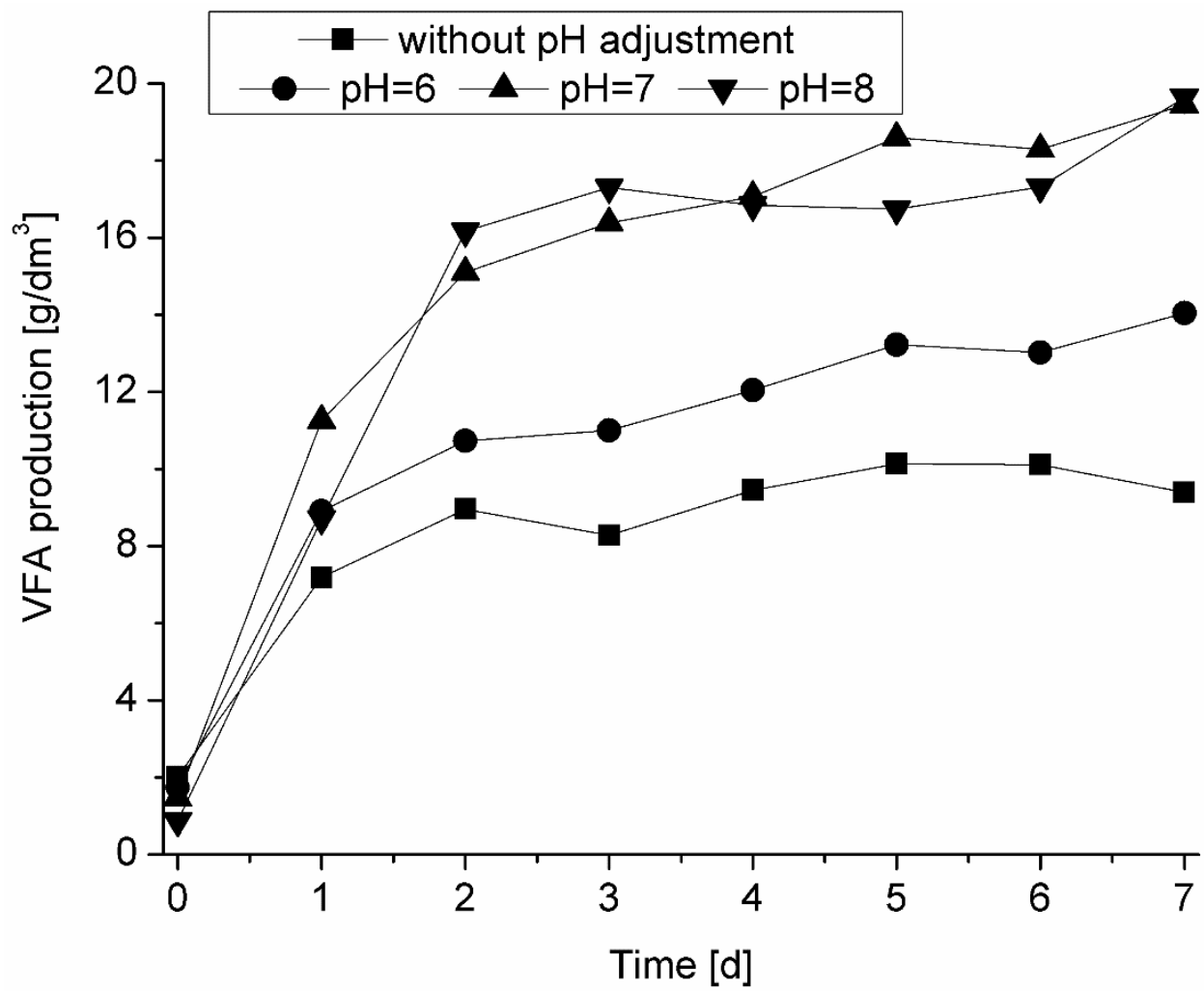

Fig. 1. The amount of VFA produced in the dark fermentation process carried out at $\mathrm{pH} 6,7,8$ and without the $\mathrm{pH}$ adjustment

Wang et al. [27] conducted a similar process of anaerobic fermentation of food wastes at a $\mathrm{pH}$ range of 4-6 and without $\mathrm{pH}$ adjustment. In their studies, the highest concentration of VFA was observed at $\mathrm{pH} 6$, and the lowest VFA amount was formed in fermenter without $\mathrm{pH}$ adjustment (more than 5-fold less than $\mathrm{pH}$ 6). This confirms the fact that the decrease in the $\mathrm{pH}$ value of the process has a negative impact on VFA production. This is probably because the simultaneous inhibition of acidogenic bacteria activity at low $\mathrm{pH}$ values occurs. In addition, lowering the $\mathrm{pH}$ increases the number of undissociated VFA, which inhibits the fermentation by enhancing the flow of undissociated acids across the cell membrane [14]. A high content of VFA in an acidic medium is also possible, as shown by Jankowska et al. [15], who performed the experiments using primary and waste activated sludge. In 5 days, the process achieved a high content of VFA at $\mathrm{pH} 4-5$. In the following days, there was no significant increase of VFA, which could be due to increasing concentration of methanogens [15]. Longer retention time favored the synthesis of VFA while maintaining the $\mathrm{pH}$ above 6 . 


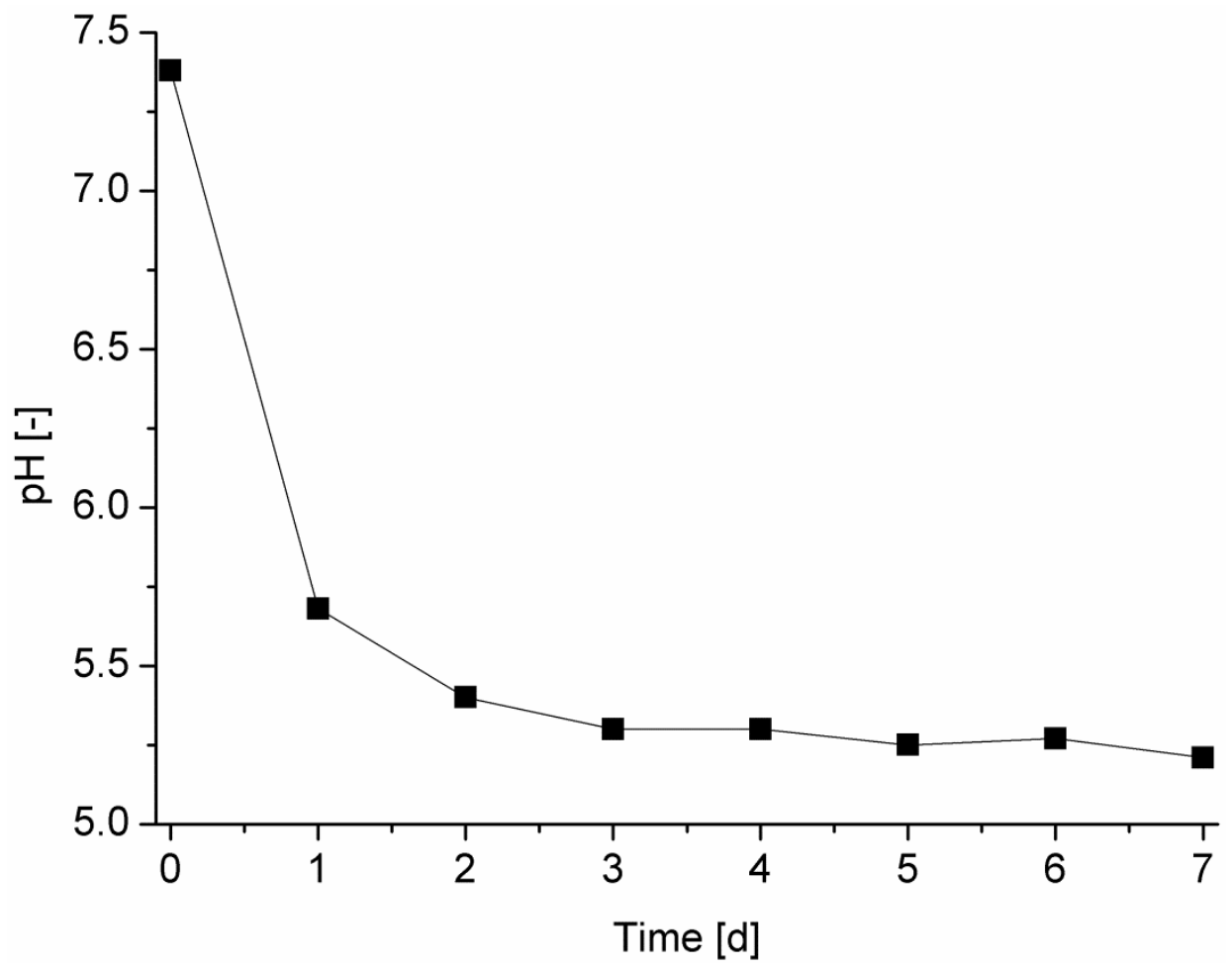

Fig. 2. $\mathrm{pH}$ fluxes during the fermentation processes conducted without adjusting the $\mathrm{pH}$

In all bioreactors the $\mathrm{pH}$ fluxes were monitored during the process. Figure 2 shows that in fermenters with $\mathrm{pH} 6,7$ and 8 the $\mathrm{pH}$ value was constant $( \pm 0.16)$, while in the fermenter without the $\mathrm{pH}$ control, the largest decrease in $\mathrm{pH}$ from 7.4 to 5.7 was observed on the first day of the process. It is associated with an intensive production of VFA during the first hours of dark fermentation. In the following days the $\mathrm{pH}$ was maintained at 5.3, although the VFA synthesis proceeded with much lower intensity (Fig. 1).

In the post-fermentation broth the composition of the synthesized VFA was also analyzed. It was observed that the largest part accounted for acetic and butyric acid. Acetic acid maintained at the highest level (approximately $80 \%$ of total fatty acids) in a bioreactor with $\mathrm{pH} 7$ and 8 . In bioreactor without $\mathrm{pH}$ control the acetic acid constituted about $60 \%$. The lowest concentration of acetic acid was observed at pH 6 (approx. $40 \%$ ). In case of butyric acid, these values ranged from 13-15\% at $\mathrm{pH} 7$ and 8, and 35-40\% for the unregulated $\mathrm{pH}$ to a value above $40 \%$ at $\mathrm{pH}$ 6. The propionic acid maintained at the level of $2-6 \%$ in all bioreactors, apart from $\mathrm{pH} 6$ where it shared approximately $10 \%$ of the total volatile fatty acids. This acid, in the acidogenic phase, is decomposed into $\mathrm{CH}_{3} \mathrm{COOH}, \mathrm{CO}_{2}$ and $\mathrm{H}_{2}$ [28]. Caproic acid in the samples with the $\mathrm{pH}$ unregulated, $\mathrm{pH} 7$ and 8 were practically undetectable $(<1 \%)$ but at $\mathrm{pH} 6$ represented more than $7 \%$. Other recognized acids (isobutyric acid, valeric acid, isovaleric acid) were $<1 \%$ of the total fatty acids. The detailed percentage composition of recognized VFA is presented in Figure 3. 


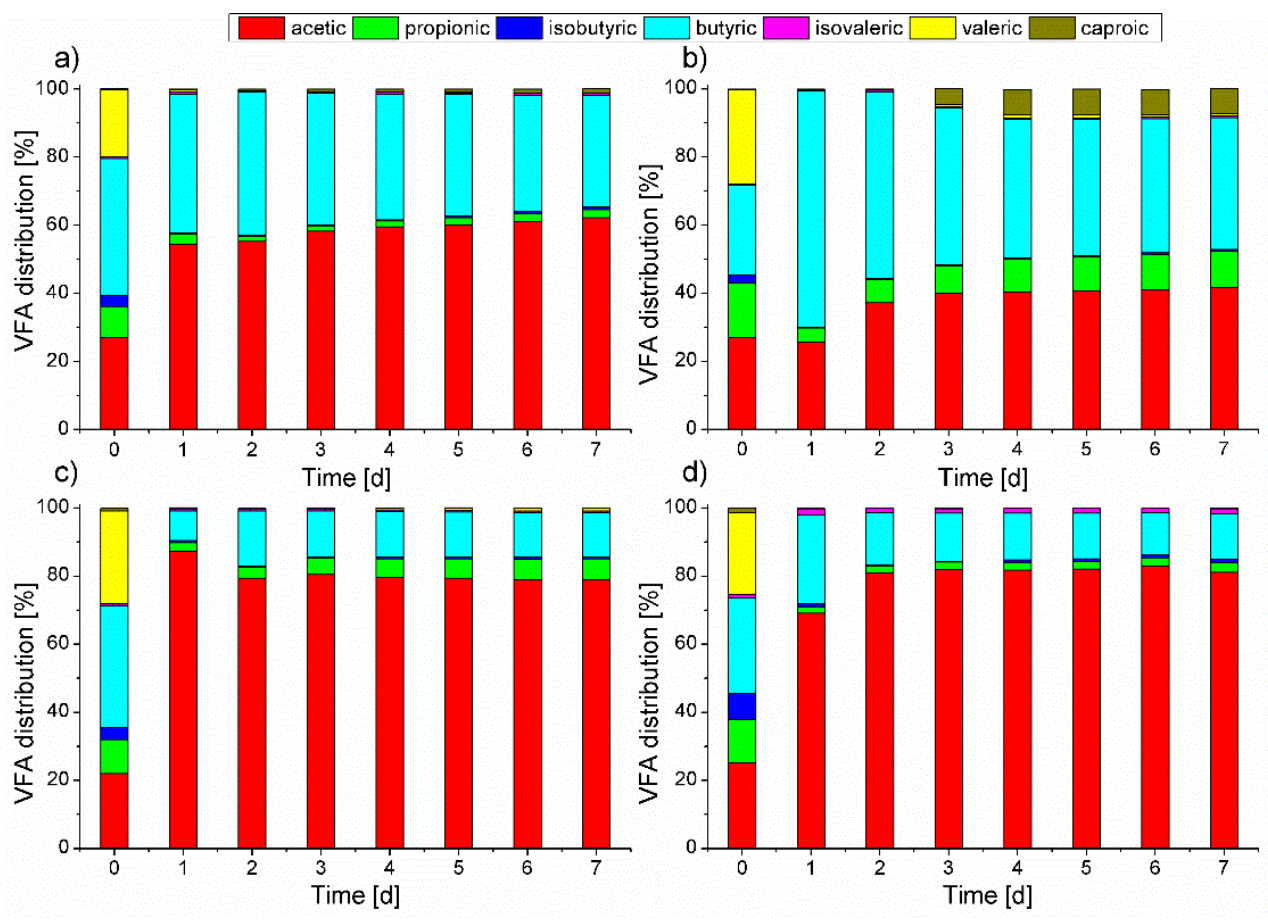

Fig. 3. Percentage share of acetic, butyric, isopropionic, propionic, isovaleric, valeric and caproic acids in the dark fermentation process: a) without $\mathrm{pH}$ control, b) with $\mathrm{pH} 6, \mathrm{c}) \mathrm{pH} 7, \mathrm{~d}$ ) and $\mathrm{pH} 8$

This is due to the microbial metabolism pathways dependent on redox potential in the cellular environment, which indicate that the reaction favors biosynthesis of butyric acid and $\mathrm{H}_{2}$ at acidic $\mathrm{pH}$. The inhibition of this process and redirection to alternative route of ethanol and acetic acid synthesis occurs at alkaline $\mathrm{pH}$ [29].

In Wang et al. [27] experiments, acetic and butyric acids constituted more than $90 \%$ of all recognized acids. In the bioreactor without $\mathrm{pH}$ control they observed approx. $60 \%$ of acetic acid and approx. $40 \%$ of butyric acid. Due to the fact that in Wang et al. [27] process, they used waste with high carbohydrate content (over $40 \%$ ), it can be concluded that the use of substrates with increased carbohydrate level may direct the synthesis to acetic and butyric acid during dark fermentation process. Most of the propionic acid was recorded at $\mathrm{pH} 6$, proving the observations referred in this article. The confirmation of the results presented in this study is also the work of Temudo et al. [16], who has studied the fermentation of glucose at a $\mathrm{pH}$ range from 4 to 8.5. Their results indicate that at lower $\mathrm{pH}$ values the most common product was butyric acid, but when the $\mathrm{pH}$ increased, the biosynthesis of butyric acid gradually decreased based on increasing acetic acid content.

From the data collected in presented experiments the changes of $\mathrm{C} / \mathrm{N}$ ratio in the post-fermentation broth were calculated (Fig. 4). In the bioreactors with $\mathrm{pH} 6,7$ and 8, the ratio of carbon to nitrogen was approx. 12. Comparing it with initial $\mathrm{C} / \mathrm{N}$ values for $\mathrm{pH}$ 6: 10.9; $\mathrm{pH}$ 7: 11.7 and $\mathrm{pH}$ 8: 12, very small change of $\mathrm{C} / \mathrm{N}$ is seen. Only in fermenter without regulated $\mathrm{pH}$ the $\mathrm{C} / \mathrm{N}$ ratio was at the level of 9.4 , while the initial $\mathrm{C} / \mathrm{N}$ value was 
10.2. Analyzing the ratio between VFA concentration and TOC value, it was noted that in all bioreactors it reached approx. 0.8 .

Referring the obtained results to available literature, the optimal $\mathrm{C} / \mathrm{N}$ ratio for the growth of acetogenic bacteria and thereby VFA synthesis in dark fermentation process range between 20-30 [30]. Due to the fact that in described process the $\mathrm{C} / \mathrm{N}$ was about half of this value, it may have a direct impact on the metabolism of microorganisms, and thus, on the amount of VFA produced. This hypothesis is confirmed by the results of [31], who showed that the optimal conditions for the production of VFA using identical substrate and inoculum as in the presented case was obtained at the $\mathrm{C} / \mathrm{N}$ ratio of $22, \mathrm{pH} 8$ and 6-day long fermentation. As it is documented by Feng et al. [13], one way of increasing the efficiency of the dark fermentation process is to add carbohydrates to the activated sludge (in the cited experiment it was rice), what increased the $\mathrm{C} / \mathrm{N}$ ratio of the reaction broth. It is particularly important since the $\mathrm{C} / \mathrm{N}$ ratio in the sludge oscillates around 7 [32].

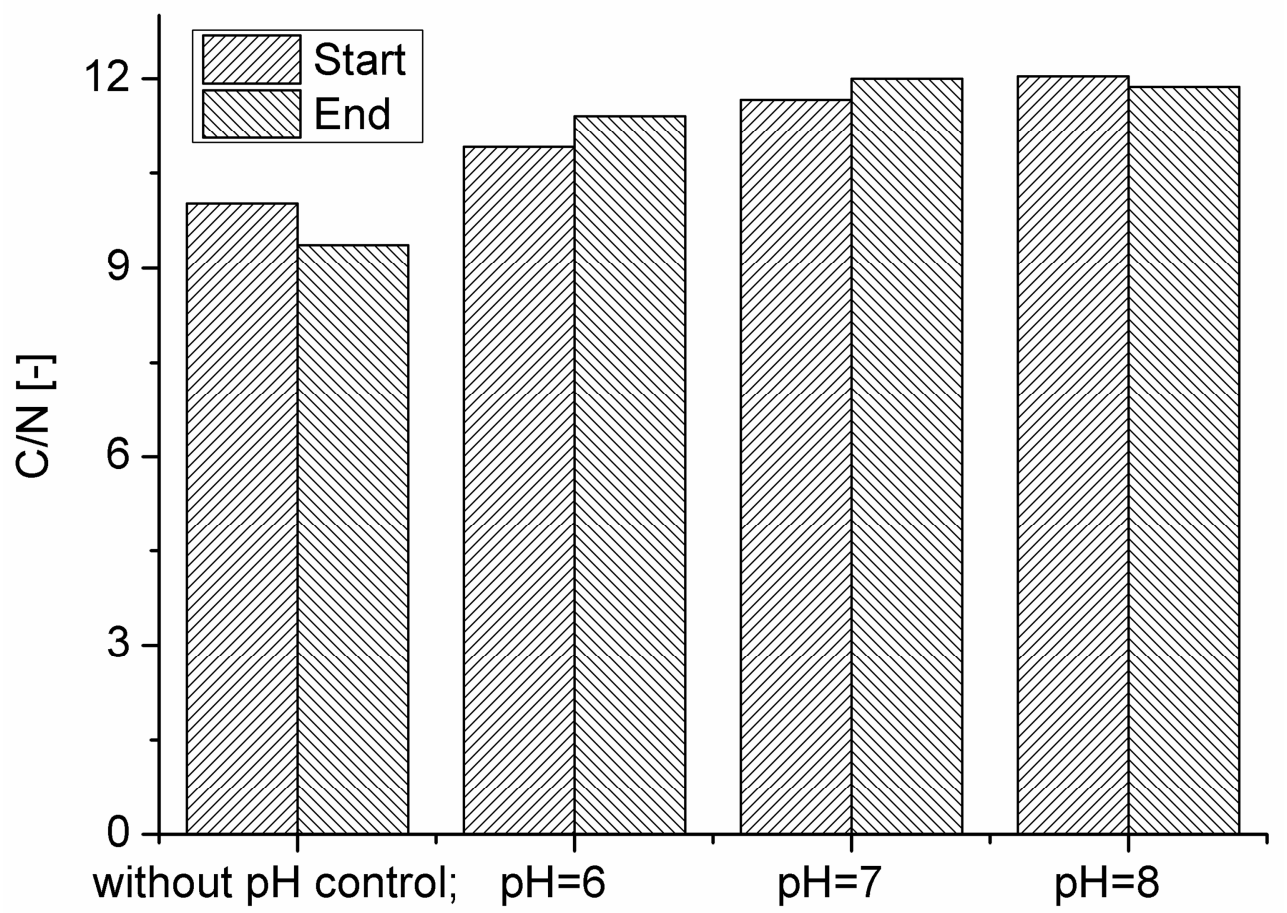

Fig. 4. $\mathrm{C} / \mathrm{N}$ ratio measured at the beginning and at the end of a process run at $\mathrm{pH} 6,7,8$ and at uncontrolled $\mathrm{pH}$

In the conducted dark fermentation processes apart from VFA, there were also produced $\mathrm{H}_{2}$ and $\mathrm{CO}_{2}$ (Fig. 5). Most $\mathrm{H}_{2}$ and $\mathrm{CO}_{2}$ were detected during the process conducted at $\mathrm{pH} 6\left(\mathrm{H}_{2}-26.48 \mathrm{dm}^{3}\right.$ and $\left.\mathrm{CO}_{2}-13.55 \mathrm{dm}^{3}\right)$. These amounts decreased with increasing the bioreactor's $\mathrm{pH}$. The smallest amount of $\mathrm{H}_{2}$ and $\mathrm{CO}_{2}$ was formed in bioreactor with a non-regulated $\mathrm{pH}\left(\mathrm{H}_{2}-4.29 \mathrm{dm}^{3}\right.$ and $\left.\mathrm{CO}_{2}-4.19 \mathrm{dm}^{3}\right)$. For the rest of the processes the ratio between generated $\mathrm{H}_{2}$ and $\mathrm{CO}_{2}$ reached 1.03 in the fermentor without $\mathrm{pH}$ adjustment; 0.82 for $\mathrm{pH} 8$ and 1.00 for $\mathrm{pH} 7$. 
These results confirm Temudo et al. [16] studies, who investigated the glucose fermentation at different $\mathrm{pH}$ values by mixed cultures of anaerobic bacteria. Monitoring the $\mathrm{H}_{2}$ content in the various samples, they observed that it decreased with an increase of $\mathrm{pH}$ (from 4 to 8.5). They concluded also, that it is directly linked to the production of formic acid. In this study, formic acid was not identified, so direct correlation cannot be confirmed. Slightly different results were obtained in Lee et al. [9] work, where the dark fermentation process was carried out using $\mathrm{KW}$ at a $\mathrm{pH}$ range between 5.5-7. The $\mathrm{H}_{2}$ production correlated with the synthesis of VFA in that case showed that at higher $\mathrm{pH}$ values dark fermentation process was aimed at $\mathrm{H}_{2}$ synthesis (maximum at $\mathrm{pH}$ 7). In contrast, at $\mathrm{pH} 5.5$ practically no $\mathrm{H}_{2}$ was generated, however, the highest concentrations of VFA, reaching $6.0 \mathrm{~g} / \mathrm{dm}^{3}$, was reported. Those differences might appear due to the character of the fermentation processes, which ran under thermophilic conditions $\left(55^{\circ} \mathrm{C}\right)$. It probably has a direct impact on the activity of distinct microorganisms, different from those which lead the process in mesophilic conditions [9].

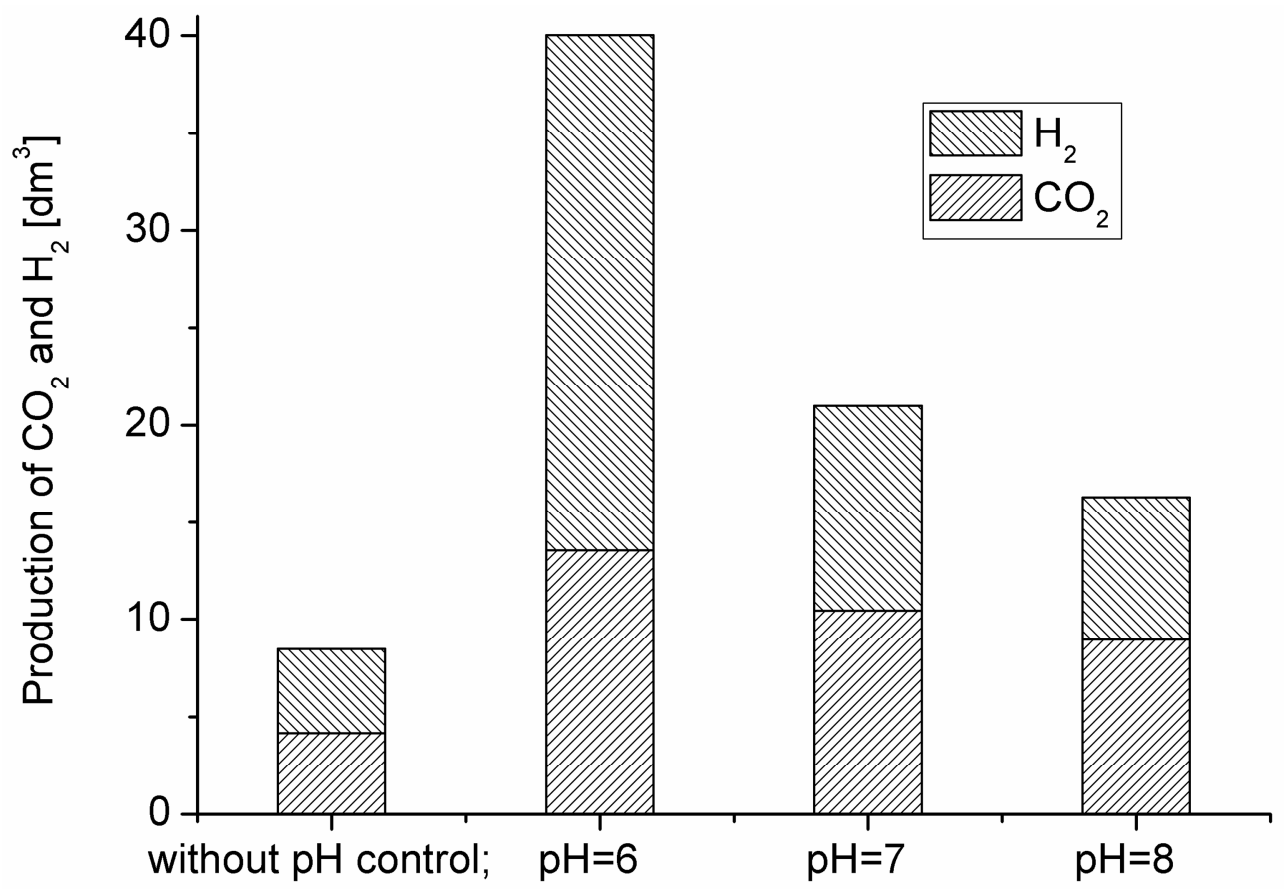

Fig. 5. The amount of $\mathrm{H}_{2}$ and $\mathrm{CO}_{2}$ produced at different $\mathrm{pH}$ values at the end of the process

Complementary to the analysis of data collected in this experiment there was performed a carbon balance of the dark fermentation process. In presented calculations it is assumed that the carbon included in $\mathrm{KW}$ was mainly converted into VFA and $\mathrm{CO}_{2}$ as a result of biochemical processes. The correctness of the carbon balance was determined by comparing the amount of carbon at the beginning and at the end of the process (Table 2). During the procedure, the amount of $\mathrm{CO}_{2}$ in the gas phase was measured. The concentration 
of carbon inside each selected gas, liquid and solid fraction was related to the volume of the growth media in which the process occurred.

Table 2

Carbon balance of the dark fermentation process carried out at different $\mathrm{pH}$ values

\begin{tabular}{|c|c|c|c|c|c|c|}
\hline \multirow[b]{2}{*}{ pH } & \multicolumn{2}{|c|}{ Start of the process } & \multicolumn{3}{|c|}{ End of the process } & \multirow[b]{2}{*}{$\begin{array}{c}\text { Balance } \\
\text { error }[\%]\end{array}$} \\
\hline & 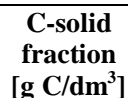 & 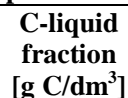 & $\begin{array}{c}\text { C-solid } \\
\text { fraction } \\
{\left[\mathrm{g} \mathrm{C}^{\mathrm{C}} \mathrm{\textrm {dm } ^ { 3 } ]}\right]}\end{array}$ & 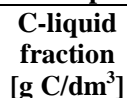 & 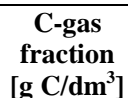 & \\
\hline 6 & 14.22 & 5.45 & 9.38 & 8.59 & 3.32 & -8.18 \\
\hline 7 & 14.55 & 5.60 & 9.33 & 9.90 & 2.56 & -8.12 \\
\hline 8 & 14.54 & 7.87 & 9.50 & 10.00 & 2.20 & 3.17 \\
\hline $\begin{array}{c}\text { Without } \mathrm{pH} \\
\text { regulation }\end{array}$ & 13.98 & 3.85 & 9.55 & 5.56 & 1.02 & 9.50 \\
\hline
\end{tabular}

The highest error in the carbon balance has been found in the process conducted without $\mathrm{pH}$ control and it was $9.50 \%$. In the series carried out at a $\mathrm{pH}$ of 8 , the mistake was $3.17 \%$, at $\mathrm{pH} 7:-8.12 \%$ and at $\mathrm{pH} 6:-8.18 \%$. The error occurred due to inaccurate analytical apparatus, as well as non-homogenous samples of the solid fraction at the start of the process, which accounted for approx. $65 \%$ of carbon at that point. In all cases the concentration of carbon in the liquid phase at the end of fermentation was higher than at the beginning of the process. The highest amount of carbon, $43.4 \%$ related to the initial phase, increased in series with the $\mathrm{pH} \mathrm{7,} \mathrm{whereas} \mathrm{the} \mathrm{lowest,} \mathrm{at} \mathrm{pH} 8$ (approx. $21 \%$ growth). As demonstrated in Table 2, together with an increase of $\mathrm{pH}$, the carbon content of the liquid phase grew relatively to the amount of carbon marked at the beginning of the process. Detected carbon in the liquid phase at the end of the process was incorporated in synthesized VFA $(80 \%)$. Comparing the amount of carbon in the solid fraction at the beginning and at the end of the process, it is seen that about $65.6 \%$ of organic carbon has not been transformed in conducted fermentation processes. This may indicate improper $\mathrm{pH}$ in the hydrolysis phase or too short duration of the fermentation process. Similar results were obtained by Cappai et al. [12], where $60-74 \%$ of the carbon from the beginning of the process was found in post-fermentation broth, suggesting restricted bioavailability of carbon in the process [12]. Based on the amount of carbon detected in the gaseous fraction at the end and at the beginning of the process, the number of organic carbon converted to $\mathrm{CO}_{2}$ was calculated. Most of the carbon from the beginning of the process $(16.88 \%)$ was transformed into gaseous phase at $\mathrm{pH}$, the lowest value $(5.72 \%)$ at non-regulated $\mathrm{pH}$.

\section{Conclusions}

Presented in following paper results confirm that environment, in which the dark fermentation process of KW was conducted, had a direct impact on the generated VFA quantity and composition. VFA synthesis proceeded most intensively in the first two days of fermentation. Maintaining $\mathrm{pH}$ in the range from 7 to 8 led to higher VFA production. Most intensive growth was observed at $\mathrm{pH} 7-8\left(19.5 \mathrm{~g} / \mathrm{dm}^{3}\right)$. No $\mathrm{pH}$ adjustment during the process caused a depletion in the production of VFA $\left(9.39 \mathrm{~g} / \mathrm{dm}^{3}\right)$. As shown in the presented article, adjusting the $\mathrm{pH}$ can significantly affect the profile and the composition of generated VFA. Lower $\mathrm{pH}(6)$ favored the production of $\mathrm{H}_{2}\left(26.5 \mathrm{dm}^{3}\right)$ and butyric acid (over $40 \%$ of total VFA), while higher $\mathrm{pH}$ values (7-8) directed the metabolic pathways into acetic acid biosynthesis ( $80 \%$ of total VFA) and lower $\mathrm{H}_{2}$ synthesis. The biggest error 
in the carbon balance has been found for the process conducted without $\mathrm{pH}$ control, and it reached $9.5 \%$. In a series carried out at $\mathrm{pH} 8$, the error was $3.17 \%, \mathrm{pH} 7:-8.12 \%$ and at pH 6: $-8.18 \%$. In all cases, the concentration of carbon in the liquid phase at the end of the fermentation process was higher than at the beginning. Most of carbon in the liquid phase $43.4 \%$ relatively to initial phase, appeared in series with the $\mathrm{pH} 7$. The smallest amount, approx. $21 \%$, was calculated at $\mathrm{pH}$ 8. At $\mathrm{pH} 6$ the highest amount of carbon from the beginning of the process was transferred into $\mathrm{CO}_{2}(16.88 \%)$. The lowest carbon was transferred into $\mathrm{CO}_{2}$ in the fermentor with unregulated $\mathrm{pH}(5.72 \%)$.

\section{References}

[1] Nguyen DD, Chang SW, Cha JH, Jeong SY, Yoon YS, Lee SJ, et al. Energy Conver Manage. 2017;135. DOI: 10.1016/j.enconman.2016.09.066.

[2] Lee WS, Chua ASM, Yeoh HK, Ngoh GC, Chem Eng J. 2014;235:83-99. DOI: 10.1016/j.cej.2013.09.002.

[3] Li Y, Jin Y, Li J. Energy. 2016;98:155-167. DOI: 10.1016/j.energy.2016.01.013.

[4] Tsai WT, Lin CC, Yeh CW. Renew Sust Energy Rev. 2007;11:838-57. DOI: 10.1016/j.rser.2005.05.005.

[5] Lee M, Hidaka T, Hagiwara W, Tsuno H. Bioresour Technol. 2009;100:578-585. DOI: 10.1016/j.biortech.2008.06.063.

[6] Charles W, Walker L, Cord-Ruwisch R. Bioresour Technol. 2009;100:2329-2335. DOI: 10.1016/j.biortech.2008.11.051.

[7] Kim S, Choi K, Kim JO, Chung J. Biodegradation. 2013;24(6):753-764. DOI: 10.1007/s10532-013-9623-8.

[8] Singhania RR, Patel AK, Christophe G, Fontanille P, Larroche C. Bioresour Technol. 2013;145:166-174. DOI: 10.1016/j.biortech.2012.12.137.

[9] Lee Z, Li S, Lin J, Wang Y, Kuo P, Cheng S. Int J Hydrogen Energy. 2008;33:5234-5241. DOI: 10.1016/j.ijhydene.2008.05.006.

[10] Lay JJ, Fan KS, Ku CH. Int J Hydrogen Energy. 2003;28(12):1361-1367. DOI: 10.1016/S0360-3199(03)00027-2.

[11] Wong Y, Wu T, Juan J. Renew Sust Energ Rev. 2014;34:471-482. DOI: 10.1016/j.rser.2014.03.008.

[12] Cappai G, De Gioannis G, Friargiu M, Massi E, Muntoni A, Polettini A, et al. Waste Manage. 2014;34(8):1510-1519. DOI: 10.1016/j.wasman.2014.04.014.

[13] Feng L, Chen Y, Zheng X. Environ Sci Technol. 2009;43:4373-4380. DOI: 10.1021/es8037142.

[14] Infantes D, Del Campo AG, Villaseñor J, Fernández FJ. Int J Hydrogen Energy. 2011;36(24):15595-15601. DOI: 10.1016/j.ijhydene.2011.09.061.

[15] Jankowska E, Chwiałkowska J, Stodolny M, Oleskowicz-Popiel P. Bioresour Technol. 2015;190:274-280. DOI: 10.1016/j.biortech.2015.04.096.

[16] Temudo MF, Kleerebezem R, van Loosdrecht M. Biotechnol Bioeng. 2007;98(1):69-79. DOI: 10.1002/bit.21412.

[17] Yuan H, Chen Y, Zhang H, Jiang S, Zhou Q, Gu G. Environ Sci Technol. 2006;40(6):2025-2029. DOI: 10.1021/es052252b.

[18] Rodríguez J, Kleerebezem R, Lema JM, van Loosdrecht M. Biotechnol Bioeng. 2006;93(3):592-606. DOI: 10.1002/bit.20765.

[19] Temudo MF, Muyzer G, Kleerebezem R, van Loosdrecht MC. Appl Microbiol Biotechnol. 2008;80(6):1121-1130. DOI: 10.1007/s00253-008-1669-x.

[20] Eaton AD, Clesceri LS, Rice EW, Greenberg AE, Franson MAH. Standard Methods for the Examination of Water and Wastewater: Centennial Edition. 21st ed. Washington: American Public Health Association; 2005. ISBN: 0875530478.

[21] Liu X, Hu X, Wang J, Song Y, Wang M, Liu R, et al. Environ Earth Sci. 2015;73:5047-5056. DOI: 10.1007/s12665-015-4194-0.

[22] He MN, Sun YB, Zou DX, Yuan HR, Zhu BN, Li XJ, et al. Procedia Environ Sci. 2012;16:85-94. DOI: 10.1016/j.proenv.2012.10.012.

[23] Zhang B, Zhang LL, Zhang SC, Shi HZ, Cai WM. Environ Technol. 2005;26(3):329-339. DOI: 10.1080/09593332608618563.

[24] Hong C, Haiyun W. Bioresour Technol. 2010;101:5487-5493. DOI: 10.1016/j.biortech.2010.02.013.

[25] Feng L, Yan Y, Chen Y. J Environ Sci. 2009;21(5):589-594. DOI:10.1016/S1001-0742(08)62312-8. 
[26] Chen H, Meng H, Nie Z, Zhang M. Bioresour Technol. 2013;128:533-538. DOI: 10.1016/j.biortech.2012.10.121.

[27] Wang K, Yin J, Shen D, Li N. Bioresour Technol. 2014;161:395-401. DOI: 10.1016/j.biortech.2014.03.088.

[28] Pilarska AA, Pilarski K, Witaszek K, Waliszewska H, Zborowska M, Waliszewska B, et al. Ecol Chem Eng S. 2016;23(1):99-115. DOI: 10.1515/eces-2016-0007.

[29] Lengeler JW, Drews G, Schlegel HG. Biology of Prokaryotes. Oxford: Blackwell Science; 1998. ISBN: 0632053577.

[30] Parkin GF, Owen WF. Fundamental of anaerobic digestion of wastewater sludge. J Environ Eng. 1986;112:867-920. DOI: 10.1061/(ASCE)0733-9372.

[31] Chen YG, Luo JY, Yan YY, Feng LY. Appl Energy. 2013;102:1197-1204. DOI: 10.1016/j.apenergy.2012.06.056.

[32] Slezak R, Grzelak J, Krzystek L, Ledakowicz S. Waste Manage. 2017;68:610-617. DOI: 10.1016/j.wasman.2017.06.024. 